\title{
Information Broadcasting Concerning Publicity and Public Participation in Development Plan
}

\author{
Norizan Rameli , Fariha Ramli ${ }^{\mathrm{b}}$ and Raihana Ahmad Jalaluddin ${ }^{\mathrm{c}}$ \\ Centre for General Studies and Co-Curricular, \\ Universiti Tun Hussein Onn Malaysia, 86400 Parit Raja, Batu Pahat, Johor \\ ${ }^{b}$ Land Development Division, Kulim Technology Park Corporation Sdn Bhd, \\ Kulim Hi-Tech Park, 09090 Kulim, Kedah. \\ ${ }^{\mathbf{c} C e n t e r}$ for Language Studies, Universiti Tun Hussein Onn Malaysia, 86400 Parit \\ Raja, Batu Pahat, Johor
}

Article History: Received: 11 January 2021; Accepted: 27 February 2021; Published online: 5 April 2021

\begin{abstract}
Malaysian Law stipulates the public society should be involved in development planning to assure thorough and comprehensive planning is made to fulfill the needs and aspirations of the society coming from multiracial and ethnicities. However, their knowledge about public participation in development planning is still in question. The participation is in fact a great opportunity for the society to play a part in shaping and influencing the objective and direction of future developments. Public participation is required in every stages of development planning such as Local Plan to ensure effectiveness of the planning system. Therefore it is crucial for the information concerning the publicity and public participation to reach targetted group through accessible broadcasting method that matched with present-day. This paper reviews their knowledge towards public participation programs. This quantitative study also discovers respondents' views on the method of information broadcasting through social media. The result shows their knowledge about public participation in planning process is considerately very low. Additionally, the study discovers that social media is highly influential among respondents where it should be used to increase public participation in development planning.
\end{abstract}

Keywords: Publicity, Public Participation, Information Broadcasting, Development Planning, Social Media

\section{Introduction}

The Town and Country Planning Department, Peninsular Malaysia (PLANMalaysia) affirms that the implementation of public participation is outlined in accordance with the provisions of Section 13 of the Town and Country Planning Act 1976 (Act 172). Before the development plan draft is approved for adoption by the Local Planning Authority (LPA), public society is given the opportunity to submit objections and contribute ideas. This shows the local community has the opportunity to be involved in future development planning. According to Ali and Ariffin (2019), public participation plays an important role in development of the country, especially for countries that practice democracy. Public participation has become the essence for development today and is significant for the contribution of valuable information towards each planned development. Thus, the process of implementing public participation at local government level is utmost important for society to be involve in the decision-making process (Gani, Awang, \& Mohamad, 2017).

The US Environmental Protection Agency refers 'public society' to consumer representatives; environmental and minority associations; trade, industrial, agricultural and labor organizations; public health; professionals; civil society; public servants; and the government and education associations (Omar \& Leh, 2009). This explains that public participation is not limited to individuals, but also associations and organizations that hold interests in development planning. As emphasized by Beierle and Cayford (2002), public participation is a mechanism implemented to involve the public society or their representatives for decision making in the administration, objectively is to ensure best choices are made. It is a desirable feature of the new planning system. Public participation is an integral part of designing and formulating policies which should not be confused with demands for more consultations between both public society and local authority (Lane, 2005). In fact, it is a fundamental feature to determine whereby public participation fails, so does the system implemented (Davies, 2001). According to Rowe and Frewer (2004), public participation is a consultative practice. It involves the public society in defining and setting goals, making decisions and forming organizations or institutions responsible for development policies.

Typically, there are two aspects that refer to public participation in the context of development in which act as tools and as goals (Samah, 2002). Public participation as a tool is referred to as a 'vehicle' all-inclusive with its own 'driver' used to bring the 'passenger' to reach the 'destination'. The intended 'vehicle', 'driver' and the 'destination' itselves are not controlled by the public society as they act only as the 'passenger' of the development. This makes it easy for them to be exploited and manipulated by certain group of interest. This type of public participation is associated with the term 'pseudo-participation', where the level of public participation in development programs is the lowest (Forde, 2005). In terms of goals achievement, public participation involves 
the entire development process that requires the public society to participate directly in order to determine the direction of desired development through the process (Samah, 2002). Newport and Jawahar (2003) argue that an effective development plan could not be carried out without the participation of the target group. Direct participation by public society in the development process could also enhance the skills, confidence, competitiveness, knowledge, and awareness that will encourage and facilitate the development process.

\section{Publicity and Public Participation in Development Planning}

The Skeffington Committee (2013) expresses the word 'publicity' means providing information on facts, arguments, and explanations to public society. According to the Skeffington Committee (2013), 'publicity' alone cannot be termed as 'public participation' but as a step towards it. In general, the term 'public participation' is defined as the participation or involvement of public society in the decision-making process of a government or its bureaucracy which involves cooperation between government and society (Quick \& Bryson, 2016). According to Alexander (2008), public participation is progressively becoming the focus of the enforcement body, government and policy makers in line with the progression of human civilization. The Skeffington Committee (2013) reports that public participation could help Local Authority to improve the quality of decision-making for public interest. The public society is also heavily involved in the planning and development process in developing countries either directly or indirectly. In fact, public participation is also a program that helps society to better understand and be informed of the planning process in their area (Goh, 1991).

The concept of public participation is closely related to the concept of democracy (Nabatchi \& Leighninger, 2015). Looking at the meaning of the word democracy by Fagence (2014), democracy means 'Demos' or people and 'Kratein' means ruling. This term describes a democratic decision that can be seen through answers to questions of "Who made the decision?" that leads to the answer of "almost everyone" in comparison to decisions made only by qualified people or one person alone as in the concept of autocracy or monarchy. A second sense emerges to determine how a decision is made. The answer to the question "How was the decision made?" is considered democratic if the decision is made by discussing, sharing of ideas, and being tolerant (Fagence, 2014). This shows that every citizen is given the right to choose and decide on what that they want.

Public participation in the planning process is generally seen as participation in the development planning in accordance with the democratic concept in which public society could participate in formulating policies and strategies that might impact the development in their area. This will ensure that the development meets the needs of the people. Public participation is a fundamental process in the development planning implemented to meet the needs and requirements of the public society through good communication and co-operation between the policy makers. According to Ngah (1991), public participation at the policy level and development plans could establish a healthy and balanced relationship between the policy enforcing body and targeted groups to create better quality of life. This means that public participation is important in providing valuable insights to the planners and the executives of the development program as the public society are the beneficiaries of the decisions in development planning. Neshkova and Guo (2012) state the importance of public participation stems from the principle of; those who are influenced by public policies must have a meaningful and equal opportunity to engage in the production of such policies. The three main factors of interest in public participation is stated by Haris (2004):

i. It is a method of obtaining accurate information on the conditions, requirements, views of the public society in which such information is incomplete, programs, and development projects are likely to fail;

ii. Individuals in public society groups will be more committed to development in their area if they are involved in the planning and preparation process as they consider it as theirs; and

iii. In many countries, public participation in development planning is considered as democratic rights.

Commonly, in the development process, public participation is viewed as the involvement of public society to formulate policies and strategies that have positive impacts on not only the development of the area involved but also the stakeholders in the area. Public participation in development planning ensures that the needs and essentials of the society are not neglected in every aspect of development planned and carried out. In other words, public participation in the development process provides them with the authority to formulate policies and development plans through suggestions, views, and objections to the draft proposed by Local Authority before any decision made. Moreover, public participation in decision-making in the government bureaucracy practices is not a new concept especially in countries such as America and Britain.

Methods of Broadcasting Information on Publicity and Public Participation in Malaysia

According to Section 12A, Act 172, the Local Authority must carry out the Local Plan Draft Exhibition Program in their area. Opportunities must be given to the society to make objections as well as views related to the stated Local Plan draft. Section 13, Act 172 dictates the Local Authority should provide a copy of the Local Plan Draft for inspection at their office or other designated locations. According to Hj. Hassan (2012), public participation in the development process is important as the public society there are actual residents of the planning area, so they are aware of what is needed. Their participation can help lead to the formation of a strategic development plan. To ensure the society is involved in the development planning process, information 
broadcasting must be made by participating agencies such as Local Authority. For publicity program, at least three broadcasting should be made in local newspapers and one of them must be published in the national-language newspaper. The information broadcasts in the newspaper must contain a notice stating the date for the copy of the Local Plan Draft to be available for review, where it will be available for review within a period of not less than four weeks from the date released (Act 172, 2006).

According to Abdullah, Ramli, and Kamaruddin (2012), publicity and public participation in Malaysia are found to still be using traditional methods. They argue that the announcement is made only to meet the requirements of the Act and not to include the public in the development planning. The study of Abdullah, Ramli, and Kamaruddin (2012) also shows that over $50 \%$ of respondents did not know about their rights in development planning. The same study also reveals that respondents did not obtain information about publicity and public participation from Local Plan Draft Exhibition. They also believe traditional media such as newspapers are not the main source of public information. Usually, publicity and public participation announcements are posted in the 'advertising space' and only about $30 \%$ of newspaper readers pay attention to that.

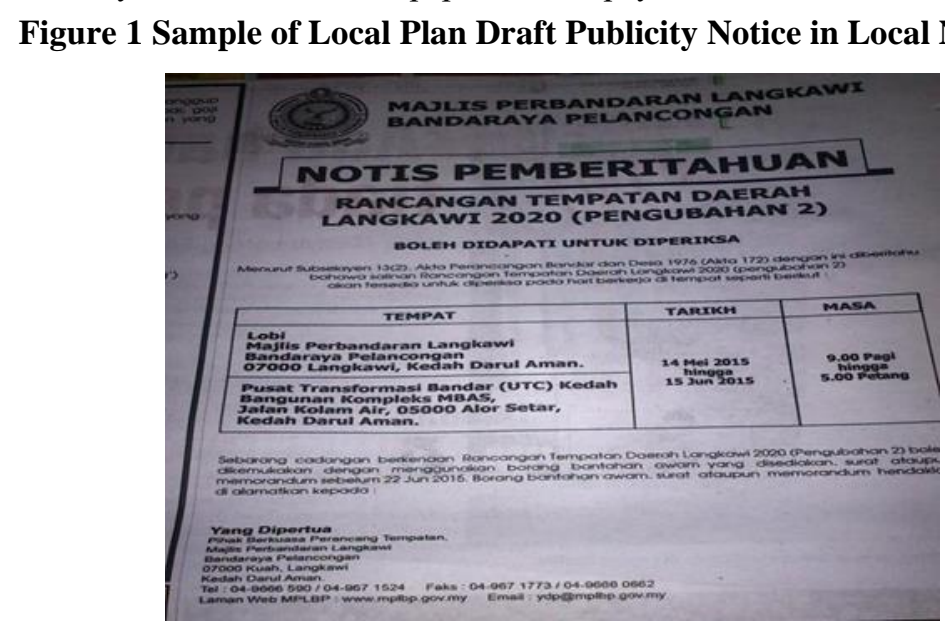

Source: Sinar Harian, June 9, 2015

PLANMalaysia has provided a specific guide for the public participation through the 'Publicity and Public Participation of Development Plan Manual'. The manual contains detailed instructions on the implementation guide and public participation. State PLANMalaysia and the Local Authority also collaborated with PLANMalaysia, Peninsular Malaysia in their efforts to engage the public society in the development planning process. Among the methods introduced are to create online protest forms, provide the GIS web, conduct Local Plan Draft exhibitions in public-focused locations such as shopping malls and use various media platforms in order to broadcast publicity programs.

Study on the public exhibition of Kedah State Structure Plan Draft by Hj. Hassan (2012) finds that only $0.037 \%$ or 708 civilians were involved out of 1.9 million total population there were involved. On top of that, only 56 objections were received by the Alor Setar Project Office Committee. Meanwhile, Ramli's (2011) study discovers a slight increase towards public participation in Local Plan Draft for Shah Alam City Council at $0.04 \%$ in 2011 as compared to $0.20 \%$ in 2007. The publicity conducted by Petaling Jaya City Council in 2012 increased by $0.02 \%$ compared to the publicity carried out in 2007, while the publicity towards Local Plan Draft at Subang Jaya Municipal Council shows static growth in public participation, which is still at $0.15 \%$ of the population. The findings of Ramli (2011) discloses the population involved in public participation in the three study areas has only increased by $0.01 \%$ from 2007 to 2012 . The study clearly shows that the performance of public participation is at an unhealthy level. Among the three local authorities, publicity conducted by the Subang Jaya Municipal Council is seen to have the lowest response from public. Ramli (2011) points out that although respondents' knowledge about Local Plans was high, the percentage involved was very low due to the issue of not knowing the date and place of publicity. Ramli (2011) argues that the use of traditional media as an agent of information broadcast is the cause of lack of public participation in publicity programs.

$\mathrm{Hj}$ Hassan (2012) concludes that public participation in development planning is a failure. This indicates that the method of broadcasting information used fails to attract the society to publicity programs. This has led to difficulties in making balanced development decisions due to the lack of feedback on the wants and needs of the public on development in their area.

\section{Methodology}

This study uses quantitative methods. The main data of this study is collected through a set of questionnaire distributed to the respondents. Respondents are from different backgrounds in terms of gender, age, race, education level, and occupation. The questions are about knowledge of public participation in development planning and the use of social media in obtaining information. The questionnaire is distributed and conducted online through social 
media sites; Twitter, Facebook, Instagram and Whatsapp messaging application. A total of 323 targeted respondents responded within three days from April 8, 2020 to April 10, 2020.

\section{Discussion}

In general, public participation in the planning process involves the public society in the process of strategy and policy planning (Goh, 1991). According to Cornwall and Gaventa (2001), public participation bridges the gap existed between public and state institutions. The survey is answered by 323 respondents online. The overall respondents are from various backgrounds where $58.8 \%$ of the respondents are female and the rest are male. The majority of respondents are Malays (74.6\%), Chinese (17.0\%), Bumiputera Sabah / Sarawak (4\%), Indian (3.1\%), and others $(1.2 \%)$. Of the total 323 respondents, $50.5 \%$ of the respondents live in urban city areas, $27.2 \%$ in villages, $10.5 \%$ in small towns, and $8.7 \%$ and $3.1 \%$ in the suburbs and inland. Table 1 shows the background of the respondents.

Table 1 Respondents Demography

Details Percentage

\begin{tabular}{|c|c|}
\hline Gender & \\
\hline Male & 41.2 \\
\hline Female & 58.8 \\
\hline \multicolumn{2}{|l|}{ Age } \\
\hline $18-30$ & 58.2 \\
\hline $31-40$ & 33.1 \\
\hline $41-50$ & 0.3 \\
\hline $51-60$ & 5.3 \\
\hline$>61$ & 3.1 \\
\hline \multicolumn{2}{|l|}{ Race } \\
\hline Malay & 74.6 \\
\hline Chinese & 17.0 \\
\hline Indian & 3.1 \\
\hline Bumiputera Sabah/Sarawak & 4.0 \\
\hline Others & 1.2 \\
\hline \multicolumn{2}{|l|}{ Education Level } \\
\hline SPM & 5.9 \\
\hline STPM/Diploma & 18.3 \\
\hline Bachelors Degree & 63.2 \\
\hline Masters/PhD & 11.1 \\
\hline Others & 1.4 \\
\hline \multicolumn{2}{|l|}{ Employment Sector } \\
\hline Services & 18.5 \\
\hline Business & 9.0 \\
\hline Government & 11.5 \\
\hline Self-employed & 10.5 \\
\hline Students & 12.3 \\
\hline Others & 3.2 \\
\hline Unemployed & 35.0 \\
\hline \multicolumn{2}{|l|}{ Land Ownership Status } \\
\hline Yes & 76.4 \\
\hline No & 25.4 \\
\hline
\end{tabular}




$\begin{array}{lc}\text { Residing Location } & \\ \text { City } & 50.5 \\ \text { Suburbs } & 8.7 \\ \text { Small town } & 10.5 \\ \text { Village } & 27.2 \\ \text { Inland } & 3.1\end{array}$

To measure the effectiveness of information broadcasting on public participation, this paper analyzes whether respondents know about development plans such as Local Plans, aware of their rights and participation in development planning or have been involved in any publicity program. A total of $61.3 \%$ of respondents are found to be unaware of development plans and $73.1 \%$ are unaware of their rights in development plans. This concludes that respondents' knowledge about the plans and their rights in development planning are low. The study also discovers that $93.1 \%$ of respondents never participated in any publicity program, of which $86.6 \%$ said they are unaware of the existence of the program. In spite of this finding, the local authorities have yet to act aggressively in ensuring that the public society has unlimited access to information on development programs in their area. Considering findings of Abdullah, Ramli, and Kamaruddin (2012) and Hj Hassan (2012), this analysis has clearly shown that for almost 10 years, the broadcasting methods used by the Local Authority are still ineffective. This also illustrated that information about publicity programs is not yet reaching the targeted group.

Figure 2 Reasons To Not Participate in Publicity Programs

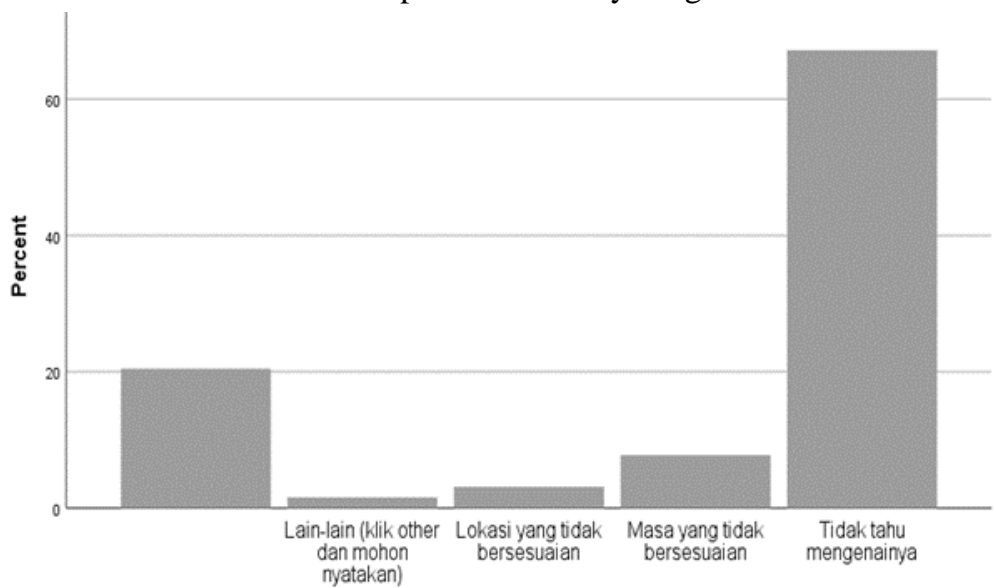

(Others, Unsuitable locations, Unsuitable time, No information) Crosstab analysis of respondent's location and knowledge of development plans finds that the distribution of respondents in the city who did not know about the development plan is more than the respondents who are aware about it. The same frequency distribution is found at each location. (Refer to Table 2).

Table 2 Crosstab Analysis between Respondents' Location and

Knowledge about Development Plans

Did you know about your rights towards Local Plan

Draft?

No

City

Village

Inland

Small town

Suburbs
$76.1 \%$

$67.0 \%$

$50.0 \%$

$85.3 \%$

$67.9 \%$
Yes

Total

$23.9 \%$

$33.0 \%$

$50.0 \%$

$14.7 \%$

$32.1 \%$

\section{$100.0 \%$}

$100.0 \%$

$100.0 \%$

$100.0 \%$ 
The majority of respondents $(65.3 \%)$ finds that the practice used in broacasting information about public participation in development plans was ineffective. $91.6 \%$ of respondents state that they did not get enough information about development planning in their area. With high percentage of respondents not having sufficient information, it appears that the current method of broadcasting information used by the responsible task force is ineffective. This finding clearly indicates that the authorities need to use other alternatives for more effective broadcasting. Authorities should also adapt and adopt to the current information broadcasting platform that is accessible to all groups.

Looking at the Malaysian Communications Commission Report in 2018, the percentage of internet users in the country in 2018 stands at $87.4 \%$, a growth of $10.5 \%$ from $76.9 \%$ in 2016 . There are about 28.7 million internet users which increases from 24.5 million in 2016. As much as $86.4 \%$ Internet users use social media (Malaysian Communications Commission, 2019). The Malaysian Communications Commission (2019) also explains that social media has become an important tool for connecting people, building communities, voicing views, as well as marketing and advertising business. The survey estimates that there will be approximately 24.6 million social network users in 2018, out of which, 97.3\% have Facebook accounts, making it the most widely held social networking platform in the country. This is followed by Instagram accounts $(57.0 \%)$ and YouTube (48.3\%), Google+ (31.3\%), Twitter (23.8\%) and LinkedIn (13.3\%) (Malaysian Communications Commission, 2019). This justification is a strong reason for this study to explore the views of respondents about the method of presenting and sharing information through social media networks. The respondents $(98.5 \%)$ believe that the use of social media applications today could attract the society to be involved in formulating development planning strategies. The study discovers majority of respondents (92.6\%) were active on social media and (92.6\%) gained information from social media. $68.4 \%$ respondents suggested that they are confident on the authenticity of information from social media if they were provided by the authorities and the government. $98.5 \%$ agree that it is relevant for local authorities to use social media such as Facebook, Twitter, Instagram to broadcast information on development planning.

According to Aladhadh, Zhang, and Sanderson (2019), social media is a platform providing information on a wide range of things. Relationships with stakeholders that once are not accessible through traditional media is now happening thanks to new technological innovations related to social media (Fardous, Du, Choo, \& Huang, 2017). Wattal, Schuff, Mandviwalla, and Williams (2010) explain the potential use of social communication tools have opened up the possibilities for transformation and modernization of public administration, creating mutually beneficial relations between the public society and the government.

Based on the analysis, several important findings related to this study have been clarified. In general, with the explosion of technology in this Industrial Revolution 4.0, Local Authorities must find new broadcasting platform to deliver sufficient information to public society. This is to ensure the active participation of them in every planning process. Here are the summaries of the findings:

i. An analysis about the public society knowledge on development planning and Local Plan has been made. Resulting from all these, it is concluded that their general knowledge and awareness towards the Local Plan and rights in the process of drafting the Local Plan is still very low. An alternative platform such as social media should be used by the Local Authority to broadcast information.

ii. Public participation in the planning process is still very low. This is because the society is not given full disclosure and there is no diversity of medium in broadcasting information to the public.

iii. The findings of this analysis establish that social media holds high impact towards the respondents. Social media platforms are seen as new media that take over and replace traditional media beliefs such as newspapers where they offer the possibility of social communication and act as a key agent in broadcasting information. The analysis also shows a high degree of trust in the information provided by social media.

iv. Social media is seen as the latest trend in the broadcasting and acknowledgement of information. It is best used by the Local Authority as a medium of interaction with the public society. The local authority should take this initiative to raise public kowledge and awareness.

v. The current phenomenon explains that the public society is more likely to obtain information through social media than traditional media such as newspapers. The information can be viewed more effectively online, as it can be accessed anytime as long as the data is not deleted by the social site moderator rather than the method of broadcasting in newspaper where advertisements are only displayed within three days. This clearly shows the usage of social media seems to be more effective over time than traditional media use.

\section{Conclusion}

Concisely, it is seen in the debate on the effectiveness of social media in the industrial sector. The use of social media has been proven effective by Air Asia. According to former AirAsia X CEO, the use of social media like Twitter could help airlines reduce costs compared to traditional methods of advertising through television or radio. According to him, social media is also used by Air Asia to address problems as well as to make online sales (The Star, August 27, 2013). This shows that the local authority also has the opportunity to integrate methods to 
broadcast development planning publicity information such as Local Plans using social media thus minimizing the use of traditional methods therefore helping to reduce costs. Local authorities need to pay close attention to public participation in each development planning as each resident in the public society has different interests or needs. A community living together will never have the same needs or interests over a period of time. This requires effective planning that involves all blocs and not just to meet the needs of one particular group but might not engage to other group.

"When a number of men are living together in one society, it is apparent that there is not total compatibility between their wants - either at any one moment or over a period of time. Sadly what would help to satisfy some would at the same time impinge on the welfare of others".

Roberts, 1974

This is a way of creating possible engagements not only between public society members of different groups, but also between members of the Local Authority when development is set out in the Local Plan for future development. The use of social media as means of communication could open up the possibilities for transformation and modernization of the method of broadcasting information on development planning thus establishing close ties that benefit all, especially the public society and the Local Authority.

\section{References}

1. Abdullah, Ishak Che, Fariha Ramli, dan Siti Mazwin Kamaruddin. 2012 . "Social Networking sites as a Medium to Disseminate Planning Information." Conference on Urban Planning \& Management in Malaysia. Kuala Lumpur: Malaysian Institute of Planner. 1-15.

2. Abelson, Julia, dan Jonathan Lomas. 1996. "In search of informed input: A systematic approach to involving the public in community decision making." Healthcare Management Forum. Los Angeles: SAGE Publications.

3. Aladhadh, Suliman, Xiuzhen Zhang, dan Mark Sanderson. 2019. "Location impact on source and linguistic features for information credibility of social media." Online Information Review 1 (2019): 119.

4. Alexander, Ernest. 2008. "Public participation in planning-a multidimensional model: The case of Israel." Planning Theory \& Practice 9 (1): 57-80.

5. Ali, Mohd Azhar Mohamed, dan Kadir Arifin. 29-35. "Factors Contributing To The Success And Weakness Of Public Participation In Local Plans At Local Authority Malaysia: A Review.” Asian Journal Of Environment, History And Heritage 3 (2): 2019.

6. Cornwall, Andrea, dan John Gaventa. 2001. "Bridging the gap: citizenship, participation and accountability." PLA notes 40 (2001): 32-35.

7. Davies, Anna R. 2001. "Hidden or hiding? Public perceptions of participation in the planning system." Town planning review 72 (2): 193-216.

8. Fagence, Michael. 2014. Citizen participation in planning. Jld. 19. Amsterdam: Elsevier.

9. Fardous, Jannatul, Jia Tina Du, Kim-Kwang Raymond Choo, dan Songshan Huang. 2017. "Investigating mobile social media users? Behaviors in tourism collaborative information seeking." Conference Human Information Interaction and Retrieval. Oslo: Association for Computing Machinery. 395-397.

10. Forde, Catherine. 2005. "Participatory democracy or pseudo-participation? Local government reform in Ireland." Local Government Studies 31 (2): 137-148.

11. Gani, Arni Abdul, Khairil Wahidin Awang, dan Abdullah Mohamad. 2017. "Exploring the public participation practices in planning for sustainable tourism in Malaysia." Dalam Balancing development and sustainability in tourism destinations, 211-219. Singapore: Springer.

12. Goh, Ban, Lee. 1991. Urban Planning in Malaysia: History, Assumptions, and Issues. Kuala Lumpur: Tempo Pub. (M).

13. Hj. Hassan, Yaakob. 2002. "Penyertaan Awam: Kejayaan dan Kegagalannya.” Jurnal Pengurusan Awam 9 (1): 67-84

14. Lane, Marcus B. 2005. "Public participation in planning: an intellectual history." Australian Geographer 36 (3): 283-299.

15. Malaysia Government. 2006. Town and Country Planning Act (Act 172) (Incorporating all amendments up to 1 January 2006). Kuala Lumpur: The Commisioner of Law Revision.

16. Malaysian Communications and Multimedia Commission. 2019. Internet Users Survey 2018. Cyberjaya: Malaysian Communications and Multimedia Commission.

17. Muller, Justin. 2019. Malaysia: number of social network users 2017-2023. 20 Februari. Accessed April 13, 2020. https://www.statista.com/statistics/489233/number-of-social-network-users-in-malaysia/.

18. Nabatchi, Tina, dan Matt Leighninger. 2015. Public participation for 21st century democracy. New Jersey: John Wiley \& Sons.

19. Neshkova, Milena I, dan Hai Guo. 2012. "Public participation and organizational performance: Evidence from state agencies.” Journal of Public Administration Research and Theory 22 (2): 267-288. 
20. Newport, Jeyanth K, dan Godfrey GP Jawahar. 2003. "Community participation and public awareness in disaster mitigation.” Disaster Prevention and Management: An International Journal 12 (1): 33-36.

21. Ngah, Kamarudin. 1991. Pengenalan penyertaan awam. Kuala Lumpur: Dewan Bahasa dan Pustaka.

22. Omar, Dasimah, dan Oliver Ling Hoon Leh. 2009. "Malaysian development planning system: Kuala Lumpur structure plan and public participation.” Asian Social Science 39-14.

23. Quick, Kathryn S, dan John M. Bryson. 2016. "Public participation." Dalam Handbook on theories of governance, 1-12. Cheltenham: Edward Elgar Publishing.

24. Ramli, Fariha. 2011. Social Networking Sites as a New Medium in Disseminating Planning Information for Public Participation. Final Year Study, Shah Alam: Universiti Teknologi Mara.

25. Roberts, Margaret. 1974. An introduction to town planning techniques. Jld. 91168910. London: Hutchinson.

26. Rowe, Gene, dan Lynn J. Frewer. 2004. "Evaluating public-participation exercises: a research agenda." Science, technology, \& human values 29 (4): 512-556.

27. Samah, Asnarulkhadi Abu. 2002. "Community Empowerment Towards Achieving Sustainable Development." Cities in the 21st Century 10 (2002): 221-231.

28. Skeffington Committee. 2013. People and planning: Report of the committee on public participation in planning (The Skeffington Committee report). London: Routledge.

29. The Star. 2013. Dreams do come true. 27 August. Accessed April 10, 2020. https://www.thestar.com.my/business/sme/2013/08/27/dreams-do-come-true. 